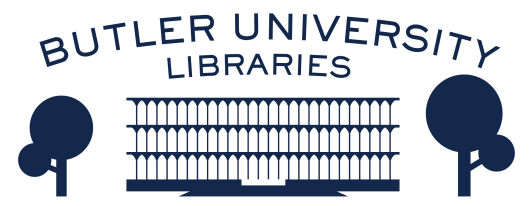

Journal of Hindu-Christian Studies

Volume 20

Article 15

January 2007

\title{
2007 Annual Society Meeting Report
}

Follow this and additional works at: https://digitalcommons.butler.edu/jhcs

Part of the Religion Commons

\section{Recommended Citation}

(2007) "2007 Annual Society Meeting Report," Journal of Hindu-Christian Studies: Vol. 20, Article 15.

Available at: https://doi.org/10.7825/2164-6279.1390

The Journal of Hindu-Christian Studies is a publication of the Society for Hindu-Christian Studies. The digital version is made available by Digital Commons @ Butler University. For questions about the Journal or the Society, please contact cbauman@butler.edu. For more information about Digital Commons @ Butler University, please contact digitalscholarship@butler.edu. 


\title{
REPORTS AND NEWS
}

\author{
Society for Hindu-Christian Studies \\ 2007 Annual General Meeting \\ November 16-17, 2007
}

The 2007 Annual General Meeting of the Society for Hindu-Christian Studies will be held at the American Academy of Religion/Society for Biblical Literature 2007 Annual Meeting in San Diego, California. Please contact Chad Bauman, Secretary, at cbauman@butler.edu for more information.

\section{FRIDAY, NOVEMBER 16, 2007}

7:00-9:30 PM PANEL DISCUSSION: "How We Do Hindu-Christian Studies"

(Manchester Grand Hyatt San Diego, Room Molly B)

This panel seeks broad audience participation in a discussion of methods, theories, and approaches in the field of Hindu-Christian studies. Panelists will make brief remarks based on papers that will be made available in advance on the HCS listserv, and audience members will then be invited to join in the discussion. To sign up for the listserv or to get copies (after Nov. 2), please email: cbauman@obutler.edu.

T. S. Rukmani, Concordia University, Presiding

Harold Coward, University of Victoria

Hindu-Christian Studies: A Retrospective

Susan Abraham, Harvard Divinity School

Theological Approaches to Hindu-Christian Studies

Brian K. Pennington, Maryville College

Historical-Critical Approaches to Hindu-Christian Studies

Arvind Sharma, McGill.University

Hindu-Christian Studies Through the Lens of Ethics

Catherine Cornille, Boston College

Missiology and Hindu-Christian Studies

Kristin Bloomer, University. of Chicago

Ethnography and Hindu-Christian Studies

T. S. Rukmani, Concordia University

Response: The Future of Hindu-Christian Studies 
58 Reports and News

SATURDAY, NOVEMBER 17, 2007

7:00-8:30 AM BOARD MEETING

(Manchester Grand Hyatt San Diego, Room Mohsen B)

9:00-11:30 AM PANEL DISCUSSION: "(Re-)Constructing Advaita: Rambachan's The Advaita

Worldview and Thatamanil's The Immanent Divine in Conversation"

(Manchester Grand Hyatt San Diego, Room Mohsen B)

Michael McLaughlin, Presiding

Panelists:

Michelle Voss Roberts, Rhodes College

Michael McLaughlin, St. Leo University

Joseph Prabhu, California State University

Respondents:

Anantanand Rambachan, St. Olaf College

John J. Thatamanil, Vanderbilt University

11:30 AM BUSINESS MEETING

Corinne Dempsey, Presiding

\section{Report of the Seminar on Brahmabandhab Upapdhyay}

THE Seminar, held at the Vidyajyoti Faculty of Theology in Delhi on January 22, 2007 and attended by about two hundred participants, was organized to commemorate the centenary of the death of an important Indian freedom fighter and Christian theologian Brahmabandhab Upadhyay (né Bhavanicharan Bandyopadhay, anglicized as Banerji), 1861-1907, an important figure who was a disciple of Keshab Chandra Sen, a youthful friend of Naren Dutta, better known as Swami Vivekananda, and a mature friend of Rabindranath Tagore and his colleague in the educational enterprise of Shanti Niketan. He had an important part in creating an anti-colonial mood in Bengal in the early years of the twentieth century. In 1891 he had converted to the Christian faith and was admitted into the Catholic Church. He wrote much for Catholic apologetics and explanation of the faith, started what may be the earliest models of journals devoted to Indian Christian theology and to interreligious dialogue (especially the monthly
Sophia), and died as a prisoner of the British charged with the crime of conspiracy against the (colonial) Government.

The Seminar was opened with a half-anhour projection of a Documentary Film prepared by the students of the Vidyajyoti College on the life of Upadhyay. The inaugural lecture was chaired by the Vice-Chancellor of the Vidyajyoti College, Dr. Hector D'Souza, S.J. and was delivered by Professor Julius J. Lipner of the School of Divinity, University of Cambridge, U.K., who dealt on "Brahmabandhab Upadhyay's Significance for the Twenty-first Century." The lecture has been published in the Vidyajyoti Journal of Theological Reflection, 71 (2007):165-184. He took up three issues, what he called the "nativisation" of (the Christian) faith, the issue of Patriotism, and the challenge that the Dalit movement and theology presents to his Sanskritic form of Indian theology. In all three areas the speaker pointed out the limitations of the work of Upadhyay, yet he 